\title{
COLOURIMAGERY IN THE HAIKU POEMS OF IMAGISTS POETS
}

\author{
Dr. Manisha Sharma (Pandey) \\ Professor of English
}

M.J.B. Govt. Girls P.G. College, MotiTabela, Indore (M.P.)

Imagism was a movement in early 20th century Anglo-American poetry that favoured precision of imagery and clear, sharp language. Imagists stressed on the direct treatment of the subject matter and strictly adhered to the rule that even a single word was not used unnecessarily. Imagists used the exact word instead of decorative words and rejected most 19th century poetry as cloudy verbosity. Imagist poets were influenced by Japanese Haiku, poems of 17 syllables which usually present only two juxtaposed images. Ezra Pound has made a conscious study of the Japanese Haiku. According to Pound, Japanese make a wonderful use of Haiku where they usually use a single image. A haiku is a haiku because all the images it conveys occur simultaneously in a person's present perceptions of the world. Ezra Pound is one the major exponents of imagist school who gave systematic theory of modernism. Ezra Pound's In a Station of the Metro is regarded as a fine specimen of Haiku. Pound recalls that once he stepped out of a "metro", train at La Concorde, and saw suddenly a beautiful face, and then another and another, and then a beautiful child's face, and then another beautiful woman. Throughout the day, Pound attempted to find words as worthy and as lovely as that sudden emotion. To his mind came an equation which was not in speech but in little sploches of colour. This feeling was the beginning of a language in colourfor Pound. Pound further elaborates that to express this kind of emotion he might find a new school of painting that would speak only by arrangements in colours. To substantiate his arguments, Pound expounds his view in Vorticism.

Colouris the primary pigment in that instance and Vorticism is art before it has spread itself into elaboration and secondary application. Pound's metro poem contains only fourteen words. Pound was influential in the creation of Imagist poetry and his poem In a Station of the Metrois an early work of modernist poetry as it attempts to break from the pentameter, incorporates the use of visual spacing as a poetic device, and does not contain any verbs.

The poem was first published in 1913 and is considered one of the leading poems of the Imagist tradition. Pound's process of deletion from thirty lines to only fourteen words typifies Imagism's focus on economy of language precision of imagery and experimenting with non-traditional verse forms. The poem is essentially a set of images that have unexpected likeness and convey the rare emotion that Pound was experiencing at that time. The soul of the poem exists in the mental process that links the two lines together.

\section{The apparition of these faces in the crowd}

\section{Petals on a wet black bough}

(Pratt, 1963-, 50)

In the first line of his poem, Pound uses the word "apparition" to mystify the visual yet unmetaphorical image "these faces in the crowd." Pound's use of the word "apparition" internalizes and at the same time externalizes his feelings about "these faces in the crowd." In other words, his 


\section{INTERNATIONAL JOURNAL of RESEARCH -GRANTHAALAYAH

use of the word "apparition" allow him and his reader to walk the edge between what can be seen and what cannot be seen, which not only mystifies the image "these faces in the crowd" but gives a depth to it. In the second line, by inserting the two adjectives "wet" and "black" in between the two flower images "Petals" and "a bough", the poet suggests that the "ki" or season, a basic component in a haiku poem, is between spring and winter and the time is probably the evening, which is between day and night. By allowing the season and the time to walk the line between spring and winter, day and night, which may represent life and death respectively, Pound succeeds in building up a mood of mystery. This mood of mystery is deepened particularly by the colour "black", whose profound darkness points to an unfathomable depth. The comparison between human faces and petals on a damp bough, calls attention to both the elegance and beauty of human life, as well as its transcience. A dark, wet bough implies that it has just rained, and the petals stuck to the bough were shortly before attached to flowers from the tree. In this way, Pound calls attention to human mortality as a whole - we are all dying. The word 'Petal' conjures ideas of delicate, feminine beauty which contrasts with the bleakness of the wet, black, bough. It is also worth noting that the number of words in the poem (fourteen) is the same as the number of lines in a sonnet.

The next poem which can be taken as a specimen of Haiku is William Carlos William's The Red Wheelbarrow. William Carlos Williams (1883-1963) was an American poet of the modernist and imagist movements. Interestingly enough he was a practicing physician. William's 'The Red Wheelbarrow' is a short haiku poem, with a wonderful use of evocative colourimagery.

The Red Wheelbarrow
So much depends
upon
a red wheel
barrow
glazed with rain
water
beside the white
chicken

(Williams, 1958, 37)

The poem is known as one of the best examples of a true imagist poem. William chose two objects in contrasting colours (red and white). Historically in literary colour symbolism, the colour red represents power and passion and evoke images of blood and love.On the contrary, white represents purity and innocence and signifies virginity. The wheelbarrow is red to display its power at the farm, and the chickens are white to show their purity. The wheelbarrows do all of the work, while the chickens lay the eggs.

The next stanza corroborates the fact that it has just finished raining by stating that the wheelbarrow is "glazed with rain / water". Rain can symbolize both turmoil, and cleaning. This can be compared to the biblical account of Noah in which God was angry at his people so he sent rain to flood the world. Although disorder ensued, the word was purified. The pictorial poem gives a beautiful message. Life will not always be sunny 'Rain will come'. However, dependable friends will enable survival. 


\section{INTERNATIONAL JOURNAL of RESEARCH -GRANTHAALAYAH

Wallance Stevens (1879-1964),is one of America's most respected poets. He was a master stylist, employing an extraordinary vocabulary and a rigorous precision in crafting his poems. But he was also a philosopher of aesthetics, vigorously exploring the notion of poetry as the supreme fusion of the creative imagination and objective reality. Because of the extreme technical and thematic complexity of his work, Stevens was sometimes considered a willfully difficult poet. But he was also acknowledged as an eminent abstractionist and a provocative thinker, and that reputation has continued since his death. In 1975, for instance, noted literary critic Harold Bloom, whose writings on Stevens include the imposing Wallace Stevens: The Poems of Our Climate, called him "the best and most representative American poet of our time."Stevens' poetry, as has been observed by several critics, manages to put into words the "metaphysical reality of nothingness", as Masaru V. Otake has described it. Stevens captures this essence of nothingness in his poem The Snowman, for instance. The poem that is frequently quoted as the paragon of haiku similarity is Thirteen Ways of Looking at a Blackbird.To quote from the poem:

\section{Among twenty snowy mountains. The only moving thing Was the eye of the blackbird.}

(Wallace Stevens, The Collected Poems, p. 534)

It is a perfect picture of nature: the image of the snowy mountains contrasted with the blackbird. The contrast of the images is as extreme as possible. It is white against black, the hugeness of the mountains against the tininess of the blackbird's eye, the motionlessness of the mountains against the hardly noticeable motion of the bird's eye. Why twenty mountains, one might ask. This, according to haiku theory, is of no significance. It might as well have been seven or thirteen. But they seem to have been counted, suggesting a very conscious perception of the landscape. The majestic grandness of the snowy of no significance. It might as well have been seven or thirteen. But they seem to have been counted, suggesting a very conscious perception of the landscape. The majestic grandness of the Snow Mountains signifies not only motionlessness, but in a sense death, especially because of the word snowy and its colour white.

In the second image it is not the bird that is perceived as moving but only its eye. The nuance in motion as compared between the mountains and the bird's eye is subtle, hardly recognizable. The word "moving" in the English language, moreover, bears a second connotation. Apart from referring to motion, it also means to move in the sense of touching, stirring one's emotions and feelings. Implicitly, the eye of the beholder is present in the poem, too, having been moved, stirred, by this moving thing that is only the eye of a bird. In analogy to the haiku, one might therefore argue that the poet expresses an identification of human being and nature, of the eye /me of man and the eye /me of the blackbird. This eye/I - in both its manifestations - is alive since it is moving. The snowy mountains are not moving, and only alive in a paradoxical sense of speaking the language of death. The black colour of the bird in itself signifies death as well. In looking at the snowy mountains as externalized image, the bird perceives the death that is already inherent in its very own being, though it is still alive and moving. In a sense it could be argued, this is a perfect example of moon-viewing. The colour white of the snowy mountains is the colour of death, of the idea of death in the metaphysical sense. Like the moon, this whiteness is reflected in the blackness of the bird, in the concrete death as inevitable potential contained in its very existence. But the 
reflection of the moonlight in the water does not disturb its smooth surface, nor does the moon get wet. Yet their encounter, even seeming fusion, provides a moment of insight into the majestically impending ever-presence of death to the looking eye that is part of a thing already tinged by death. Therefore motion versus motionlessness juxtaposes life and death, but in such a paradoxical sense that they may ultimately be interchanged. For long after the blackbird may have died the mountains will still be residing in the same spot, manifesting once and forever the death that is.

It is impossible to overstate the importance of the Imagists to the poetry of the 20th century. After all, they championed free verse and freed poetics from the tyranny of the pentameter. Perhaps no single document is as important as Pound's Manifesto in understanding the poetics of Modernism. Every important poet who followed - from T.S. Eliot, a Symbolist who was never associated with the group - absorbed the lessons and acknowledged a debt to Pound, as did younger poets, the likes of E.E. Cummings and Allen Ginsberg. But even these traditionalist poets have been touched by the Imagists. They are, after all, free to write what they would and in a free manner - their poems seldom ruined by the maudlin sentiment that haunted the works of Stedman and his contemporaries.

Haiku demands preciseexploration and observation on thenature. The most common technique is ajuxtaposition of two images (Japaneserenso). Traditional Japanese haikuinclude a "season word" (kigo), a wordor phrase that helps identify the seasonof the experience recorded in the poem,and a "cutting word" (kireji), a sort ofspoken punctuation that marks a pause.In English season words are sometimesomitted, but the original focus onexperience captured in clear imagescontinues. Punctuation, space, or linebreaksmay substitute for cutting words.Most haiku have no titles, andmetaphors and similes are usuallyavoided. The main concern of haiku isvividly showing the closeness of the poetand the nature as the source ofinspiration.

Therefore, a haiku startles thereader out of a rational mode of thoughtinto a deeply emotive, visionaryperception of the nature. Thisunderstanding of haiku may serve as atouchstone by which one may considerImagists' poetry. Haiku and the Imagistpoetry have several resemblances whichare undoubtedly that Haiku plays a veryvital role in the emergence of the latter.Ezra Pound, William Carlos William and Wallace Stevens in their representative poetry excel in this wonderful specimen of Haiku poetry.

\section{REFERENCES}

1. Pratt, William, 2009. The Imagist Poem: Modern Poetry in Miniature, University of New Orleans Press, New York.

2. $\quad$ Wallace Stevens, 2011. The Collected Poems, Random House, Knopf Doubled Publishing Group.

3. Williams, W.C.1958.I Wanted to Write a Poem: The Autobiography of the Works of Poet, reported and edited by Edith Heal, Boston, Beacon Press. 